УДК 378.093:7.05:687.01

DOI:

Олена Тригуб, викладач кафедра дизайну факультет мистеитв Відокремлений підрозділ "Миколаївська філія

Київського національного університету культури і мистецтв"

\title{
АКТУАЛЬНІ ПРОБЛЕМИ ФАХОВОЇ ПІДГОТОВКИ МАЙБУТНІХ ДИЗАЙНЕРІВ У ЗАКЛАДАХ ВИЩОЇ ОСВІТИ УКРАЇНИ: ТЕОРЕТИЧНІ ТА ПРИКЛАДНІ АСПЕКТИ
}

У статті виокремлені актуальні тенденції у теорії та практиці фахової підготовки майбутніх дизайнерів у закладах вищої освіти України, які стосуються розуміння термінів “професійне мислення” та “структура професійного мислення майбутнього дизайнера” та сутнісний зміст дизайнерської професійної підготовки. Аналіз наукових джерел дозволив нам сформулювати власне визначення терміну “професійне мислення (майбутнього) дизайнера”, яке нами розуміється як клієнт-орієнтована проектна діяльність яка поєднує логіку, інтуїію, мистецттво, комерцію і науку. А структура професійного мислення (майбутнього) дизайнера нами розглядається як динамічна спіраль ичиклів, які є послідовністю самодостатніх, самокомпенсаційних і самовдоскональних мікропроцесів спрямованих на інтуїнвно-художнє $і$ критичнологічне осмислення і реалізачію дизайнерського завдання.

Ключові слова: дизайнерська освіта; вища освіта; професійне мислення дизайнерів; типологія дизайну; зміст професійної підготовки дизайнерів.

Puc. 1. Лim. 12.

Olena Tryhub, Lecturer of the Design Department, Faculty of Arts, Separate subdivision "The Mykolayiv Branch of the Kyiv National University of Culture and Arts"

\section{GAPS TO STUDY IN THE VOCATIONAL TRAINING OF FUTURE DESIGNERS IN HIGHER EDUCATIONAL INSTITUTIONS OF UKRAINE: THEORETICALAND APPLIED ASPECTS}

Purpose. The aim of this article was to reveal the current trends in the theory and practice of vocational training of future designers in higher education institutions of Ukraine, which relate to the understanding of the terms like "professional thinking" and "structure of professional thinking of a future designer" and the essential content of design vocational training. Methodology. A set of theoretical general scientific methods were used to meet the research aim. Those were systematic and comparative approaches based on analysis, synthesis, comparison, induction and deduction, as well as descriptive method.

Findings. The analysis of scientific sources has allowed us to formulate our own definition of the concept "professional thinking of the (future) designer", which we understand as a client-oriented design activity that combines logic, intuition, art, commerce and science. And we view the structure of professional (future) thinking of a designer as a dynamic spiral of cycles, which are a sequence of self-sufficient, self-compensating and self-perfect microprocesses aimed at intuitive-artistic and critical-logical thinking and realization of a design task. We also found that the problem of design typology remains debatable among practicing theorists today, since the use of hierarchical (subordination) or facet (the choice of classification features independently of one another and the semantic content of the object being classified) classification systems do not provide a solution to the problem. In the foreign sources, they use the term "a list of design disciplines" which is based on the main features of the way of thinking of the designer instead of the term "a typology of design by types of objects of design". The list of design studies includes: applied arts, architecture, transport design, design of communications, configurations, engineering, graphic, fashion, game design, information architecture, industrial design, pedagogical, interaction design, interior design, landscape, light, video, process design, services, software, sound, web design. It made us convinced that with the development of technology, the above list has the potential to expand due to the fact that the principles and methods of design will adapt to other areas of human activity.

Originality. The scientific novelty of the study is in formulation of the definitions of both the concept of "professional thinking of the (future) designer" and the structure of professional (future) thinking of a designer, and while analysing the scientific literature, the content of vocational training of the designers and curriculum of the higher institutions, it was discovered a trend of deepening of interdisciplinarity, namely in the direction of crosssectoral convergence and increasing attention to the problem of formation of students' competences of self-education.

Practical value. It was specified the scope for the further investigation which is to study the possibilities of combining both trends in the model of forming the future designers' readiness for self-education on the basis of interdisciplinary approach in art institutions of higher education. 


\section{АКТУАЛЬНІПРОБЛЕМИ ФАХОВОЇ ПІДГОТОВКИ МАЙБУТНІХ ДИЗАЙНЕРІВ УЗАКЛАДАХ ВИЩОЇ ОСВІТИ УКРАЇНИ: ТЕОРЕТИЧНІ ТАПРИКЛАДНІ АСПЕКТИ}

Conclusion. The list of design disciplines is based on the main features of a designer's way of thinking. With regard to the vocational training of future designers in higher education institutions, there is a trend of deepening of interdisciplinarity, namely in the direction of cross-sectoral convergence and increasing attention to the problem of formation of students'competences of self-education.

Keywords: design education; higher education; professional thinking of designers; typology of design; content of vocational training of designers.

$\Pi$ остановка проблеми. Дизайнерська освіта в Україні є, порівняно з Свропою та Сполученими Штатами, досить новим напрямом професійної підготовки і розвивається в межах загальноєвропейських процесів, спираючись на національні освітянські та художні традиції [9].

У нашій державі проблема розвитку системи професійної підготовки дизайнерів, як культурномистецького напряму освіти, i оптимізація ії рівня якості $€$ актуальною на усіх рівнях: державному, науковому й організаційно-методичному. Про це свідчить нещодавно прийняті документи як-от: Довгострокова стратегія розвитку культури (2016 рік), Закон України "Про освіту" (2017 рік) (до якого введено Статтю "Мистецька освіта"), які визначають цілі, пріоритети й інструменти реалізації змін у системі професійної мистецької підготовки, йдизайнерської зокрема; середньостроковий план пріоритетних дій Уряду до 2020 року та плану пріоритетних дій Уряду на 2017 рік, які спрямовані на модернізацію змісту та умов надання мистецької і дизайнерської освіти; нормативні програмні документи, зокрема "Концепція гуманітарного розвитку України до 2020 р.' (2012р.), аналітичний документ "Мистецька освіта в Україні: розвиток творчого потенціалу в XXI ст.", що був розроблений у межах проекту ЮНЕСКО і Міжнародного фонду гуманітарного співробітництва (2012 р.), спрямовують науковців на пошук шляхів дослідження та розвитку феномену українського соціокультурного простору, інтелектуального потенціалу нації, збереження зв'язків між поколіннями на основі передачі молоді культурного та художнього досвіду, традицій і цінностей минулого. Значним поштовхом як для закладів вищої освіти, особливо мистецьких, так i для менеджерів культури, експертів, митців, дизайнерів стало приєднання нашої країни до півтора мільярдного фонду рамкової Програми Європейського Союзу "Креативна Європа", що дала старт практичному втіленню переваг, які Угода надає для профільних закладів освіти, культурних інституцій, цілих індустрій та власне інтеграції української культури до культурного процесу Європи. Вищезазначене спонукає науковців-педагогів до розробки нових підходів до реалізації фахової підготовки майбутніх дизайнерів.
Аналіз актуальних досліджень та публікацій. Теоретичні та прикладні аспекти мистецької освіти й естетичного виховання розкриті у наукових працях В. Бутенко, Г. Гребенюка, Т. Габреля, О. Олексюк, В. Орлова, О. Отич, В. Радкевич, О. Ростовського, О. Рудницької, В. Тименка, О. Шевнюк та ін. Теорія дизайну й художньої творчості представлені у науковому доробку Л. Безмоздіна, О. Бойчука, М. Воронова, О. Генісаретського, В. Даниленка, О. Дем'янчука, Л. Оршанського, В. Папанека, В. Прусака, В. Сидоренка та ін. Засади формування професійного мислення дизайнерів висвітлені у наукових працях Т. Бистрової, О. Генісаретського, Дж. О'Коннора, Дж. К. Джонса, В. Іващенка, А. Магомедової, М. Ньольке, І. Карімової. Проте, зважаючи на швидкоплинну трансформацію дизайнерської освіти, констатуємо, що зазначені публікації вже не достатньо відображають стан речей у цій “царині”.

Отже, метою цього дослідження визначено виокремити актуальні тенденції у теорії та практиці фахової підготовки майбутніх дизайнерів у закладах вищої освіти України.

Викладення основного матеріалу. Студіювання вищезазначених напрацювань дозволило нам простежити генезу і виокремити драйвери (від англ. driver - рушій, рушійна сила) розвитку дизайну як виду проектної творчості (професіі), які суттєво вплинули і скеровували наукові розуміння змісту і цілей дизайн-освіти. Серед ключових драйверів акцентуємо 1) розуміння суті термінів "професійне мислення (майбутнього) дизайнера" та “структура професійного мислення майбутнього дизайнера"; 2) типологія дизайну та 3) сутнісний зміст дизайнерської професійної підготовки [2].

Розглянемо підходи до інтерпретації термінів “дизайн”, “професійне мислення” та “структура професійного мислення майбутнього дизайнера". Разом з розвитком фахової підготовки дизайнерів змінювалися трактування терміну “дизайн”. У наукових джерелах різних періодів знаходимо наступні підходи до визначення зазначеного терміну, а саме: дизайн як інструмент (В. Гропіус, М. Віньєллі), дизайн як вид діяльності (процес) (Г. Парсонс [12]; Н. Дзогій; Т. Габрель [2; 3]), дизайн як результат діяльності (Т. Габрель; В. Папанек), дизайн як творча активність 


\section{АКТУАЛЬНІПРОБЛЕМИ ФАХОВОЇ ПІДГОТОВКИ МАЙБУТНІХ ДИЗАЙНЕРІВ У ЗАКЛАДАХ ВИЩОЇ ОСВІТИ УКРАЇНИ: ТЕОРЕТИЧНІ ТА ПРИКЛАДНІ АСПЕКТИ}

(В. Даниленко; В. Прусак). Зважаючи на такі підходи, змінювалися парадигмальні акценти у системі професійної підготовки дизайнерів: від розвитку естетичного потенціалу, формування творчої особистості дизайнера, здатної до гармонізації середовища у бік культивування формально-логічних здатностей майбутнього фахівця, його/її аналітичних й технологічний компетенцій, які утворюють професійне мислення дизайнера.

Проблема типології і структури професійного мислення (майбутнього) дизайнера, роль цього аспекту у проектно-творчій діяльності фахівця 3 дизайну і освітні інструменти його розвитку були предметом досліджень цілої плеяди науковців на теренах нашої держави та за кордоном [7]. Наше дослідження виявило вісім типів професійного мислення дизайнера, які теоретики дизайну та архітектури асоціюють 3 певним розумінням проектування, візуалізації і композиції об'єкта дизайну, його образним чи творчим перетворенням, його художньою чи екологічною цінністю та просторовою придатністю. Такі бачення професійного мислення дизайнера дають можливість простежити еволюцію цього поняття і системи професійної підготовки разом з ним. У дослідженнях останнього десятиріччя у наукових дискусіях домінує думка про оптимальність для вирішення дизайнерських завдань образного, творчого, візуалізаційного і композиційного типів мислення [3; 4]. Так, В. Даниленко вважає, що образне мислення $\epsilon$, у певному сенсі, інтуїтивний і підсвідомий процес який дозволяє розглядати предмет дизайну інтегровано [5]. Е. де Боно асоціює творче мислення з “нешаблонністю” (outof-the-box-thinking), інтелектуальною ініціативою, пошуком нових способів дії, видозміною раніше освоєних прийомів, схем прийняття рішення 3 урахуванням конкретної практичної ситуації, уміннями застосовувати “неявні знання" (tacit knowledge) [1]. На думку П. Енгельмейєра, творче мислення дизайнера - це стратегія психологічного синтезу досвіду дизайнера стимульована певним емоційним станом $[6,112$ - 118]. В. Турчин ототожнює композиційне мислення із візуальним та проектним мисленням [10], яке “...підкріплюється пізнавальними, технічними, художніми практиками” [10]. Отже, феномен професійного мислення (майбутнього) дизайнера нами розуміється як клієнторієнтована проектна діяльність яка поєднує логіку, інтуїиію, мистецтво, комеричію і науку. А структура професійного мислення (майбутнього) дизайнера нами розглядається як динамічна спіраль цииклів, які є послідовністю самодостатніх, самокомпенсаційних $i$ самовдоскональних мікропроцесів спрямованих на інтуїтивно-художне і критично-логічне осмислення $i$ реалізацію дизайнерського завдання. Зобразимо структуру професійного мислення (майбутнього) дизайнера у вигляді діаграми (див. Рис. 1).

Наступною науковою і прикладною проблемою на початку минулого століття стала типологія дизайну. Вона була пов'язана 3 кардинальними змінами у сфері матеріального виробництва, появою технічних засобів тиражування рукотворних виробів й тенденцією до переходу дизайнерів у їх професійній діяльності на принципи дизайнерського ставлення до виробництва, а саме: врахування балансу між естетикою й утилітарно-практичною цінністю виробу, поєднання технології виготовлення продукту 3 доречним вибором матеріалу, раціональністю конструктивних пропозицій, оригінальністю й новизною вирішення проектної задачі $[1,28]$.

На той часпочинають вирізняти й запроваджувати у освіту навчальні програми, які враховували такі напрямами дизайну як-от: промисловий (або індустріальний), графічний, архітектурний (і його піднапрям, арт-дизайн), та процесуальний [3]. Нами 3'ясовано, що серед практикуючих теоретиків проблема типології дизайнузалишається дискусійною й на сьогодні, оскільки застосування ієрархічноі (встановлення підпорядкованості) чи фасетної (вибір ознак класифікації незалежно як одна від одної, так і від семантичного змісту об’єкта, що класифікується) систем класифікації не забезпечують вирішення завдання [3].

У закордонній спеціалізованій літературі замість терміну “типологія дизайну за видами об'єктів проектування” використовується термін “перелік дизайн-дисциплін”, який базується на головних ознаках способу мислення дизайнера. Зазначений перелік дизайн-дисциплін включає: прикладне мистецтво, архітектуру, транспортний дизайн, дизайн зв'язків, конфігурацій, інженерний, графічний, моду, дизайн ігор, інформаційну архітектуру, промисловий дизайн, педагогічний, проектування взаємодій, дизайн інтер'єру, ландшафтний, світловий, відео, дизайн процесів, сервісів, програмного забезпечення, звуковий, веб дизайн $[1 ; 3 ; 8]$. Ми упевнені, що завдяки розвитку технологій, вищезазначений перелік має потенціал до розширення через те, що принципи і методи проектування будуть адаптуватися до інших сфер діяльності людини [8].

Перейдемо до окреслення актуальних тенденції у змісті дизайнерської професійної підготовки у закладах вищої освіти України. 


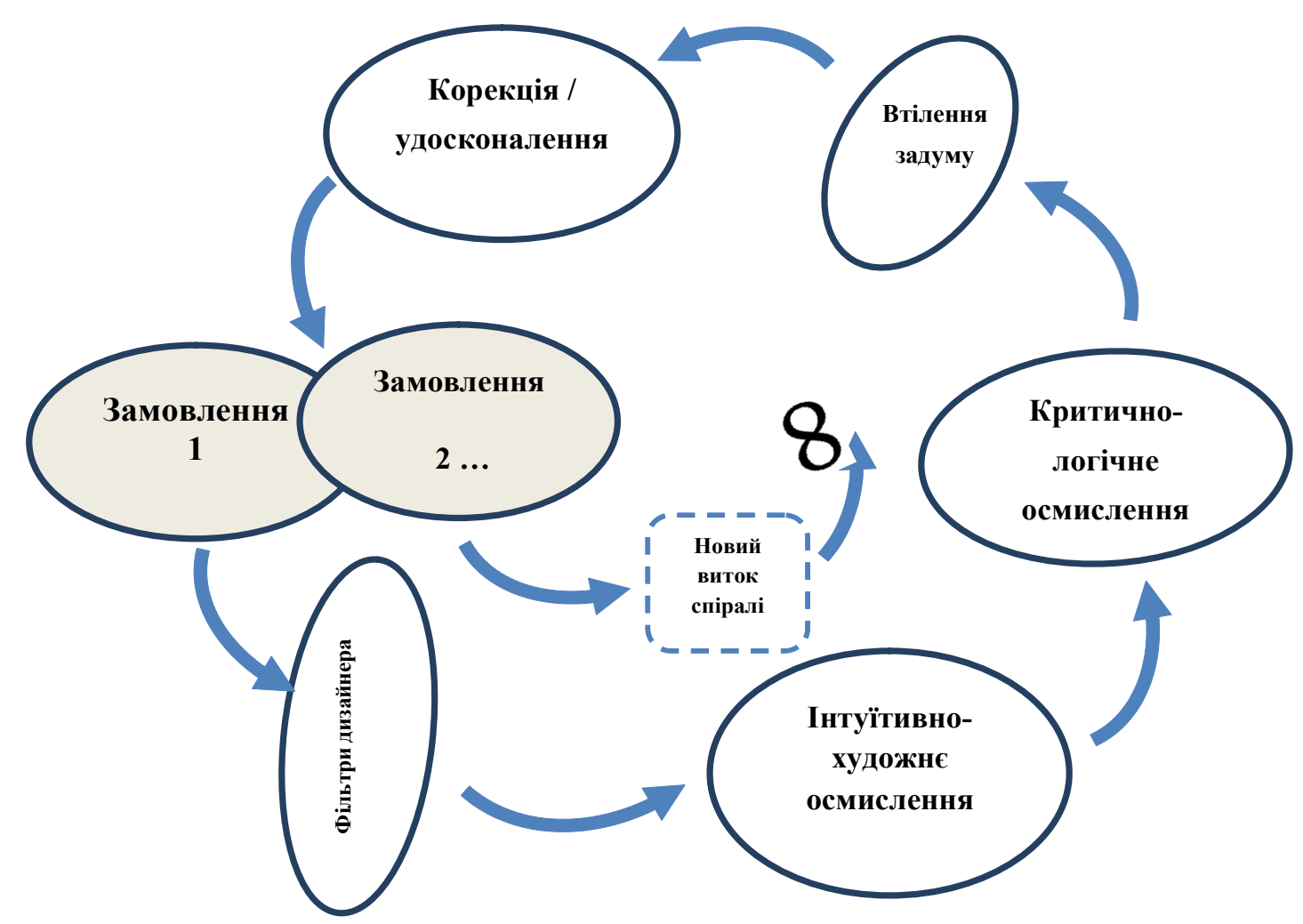

Рис. 1. Структура професійного мислення (майбутнього) дизайнера

Цінними в рамках висвітлення питання особливостей фахової підготовки майбутніх дизайнерів у закладах вищої освіти вважаємо наукові дослідження В.Я. Даниленка [5]. В них розглядаються питання теорії і історії дизайну, а також аналізується дизайнерські процеси у різних країнах, таких як: Польща, Німеччина, Фінляндія, Великобританія, Франція та інші. На фоні цих питань аналізується система вищої освіти 3 дизайну в провідних навчальних закладах Європейських країн, розглядаються взаємозв'язки між окремими дисциплінами. Науковець також наголошує на необхідності навчання і розвитку такого майбутнього фахівця-дизайнера, який би володів навичками та знаннями, необхідними для життя у мінливому, індивідуалізованому, високотехнологічному світі XXI століття, що у свою чергу вимагає перегляду педагогічних концепцій у бік їх спрямованості на підвищення педагогічної взаємодії, толерантності партнерських відносин викладача і студента, оскільки саме від гуманності взаємодії педагога та студентів залежить якість дизайн-освіти і ефективність навчально-виховного процесу [10]. На думку В. Прусака, який досліджує загальні проблеми дизайн-освіти, зокрема ті, що стосуються організації та змісту підготовки фахівців з дизайну до здійснення ними майбутньої професійної діяльності, система підготовки майбутніх дизайнерів у закладах вищої освіти України повинна інтегруватизагально-художні (фундаментальні) й фахові знання, оскільки вони формують у студента естетичні смаки та культурологічну базу професії, що $€$ частиною його(iii) професійного зростання та творчого розвитку. Науковець підтримує ідею використання блочного підходу до структурування змісту освіти майбутніх дизайнерів, суть якого полягає у вибудові процесу підготовки у інтегровані міжпредметні блоки, кожен з яких спрямований на набуття студентами певних компетенцій й на розвиток творчого й емоційно-ціннісного компонентів й певних особистісних якостей [8]. Як стверджує О. Фурса, пошук універсальних методів та стрімка акселерація адаптування зарубіжних моделей фахової підготовки майбутніх дизайнерів у закладах вищої освіти України $є$, у певному сенсі, деструктивною практикою, оскільки руйнуе педагогічну спадщину національної педагогіки. Науковець пропонує поетапно адаптувати ті нові навчальні технологій, які відповідають засадам інформаційного суспільства, принципам візуальної культури та комунікативного простору [11].

В умовах сьогодення, коли кожні два роки об'єм інформації в усьому світі подвоюється й коли виклики в індустрії дизайну з'являються ледь 


\section{АКТУАЛЬНІПРОБЛЕМИ ФАХОВОЇ ПІДГОТОВКИ МАЙБУТНІХ ДИЗАЙНЕРІВ У ЗАКЛАДАХ ВИЩОЇ ОСВІТИ УКРАЇНИ: ТЕОРЕТИЧНІ ТА ПРИКЛАДНІ АСПЕКТИ}

не щодня, традиційна система трансляції знаннєвого досвіду, що базується на принципі “сиди - слухай/читай/споглядай - повтори” вже не відповідає динаміці мислення і не викликає захвату у молодого покоління фахівців. Емпіричний огляд матеріалів конференцій у сфері педагогіки дизайн- та мистецької освіти останніх років, а саме: Міжнародних науково-методичних конференцій "Педагогічні аспекти підготовки викладачів 3 візуального мистецтва та дизайну: сучасність і перспективи” (2017 рік), “Культурні і креативні індустрії: історія, теорія та сучасні практики” (2017 рік), “Досвід розвитку креативних індустрій на базі нематеріальної культурної спадщини” (2018 рік), “Дизайн-освіта як галузь креативних індустрій” (2019 рік), дав нам змогу виокремити освітні тенденції у дизайн-освіті, які стали предметом дискусій та стратегічним орієнтиром для вирішення закладами вищої освіти. Зокрема, у закладах вищої освіти України, й мистецького профілю, спостерігається більша зацікавленість студентської молоді у розвитку їх особистісних якостей без нав'язування педагогами суб'єктивного бачення речей. Наголошується, що в українських мистецьких закладах освіти існує потреба у педагогахпрактиках, які не лише майстерно викладають, але й мають авторитет у царині дизайну. Вирішення цієї проблеми створить у вишах можливості для зближення дизайн-освіти та бізнесу через поширення практики виконання дипломних робіт на замовлення бізнес-компаній із відповідною оплатою за ринковою вартістю такої роботи. Вдалою ілюстрацією практики зближення дизайн-освіти та бізнесу може слугувати підготовка у сфері дизайну одягу (спеціальність 022 “Дизайн”) у Відокремленому підрозділі “Миколаївська філія Київського національного університету культури і мистецтв”, у навчальних планах якого значна доля навчального навантаження на другому, третьому та четвертому роках навчання припадає на дисципліни професійної та практичної підготовки - 1050 - 1080 год/рік (60\% від загального навантаження) - 3 яких 630 год на другому році навчання та 720 год на третьому та четвертому роках виділяється на виробничу практику і ще близько $30 \%$ навчального навантаження виділяється на низку таких дисципліни як: “Комп’ютерна графіка в дизайні”, “Художнє конструювання та моделювання”, “Брендінг fashion-бізнесу”, “Аналітика світових трендів“" тощо. Ми упевнені, що, оскільки наразі компанії під час рекрутингу віддають перевагу студентам, які не тільки навчені рисунку, кресленню, основам дизайну, конструюванню та ін., але й готовим до комунікації з потенційними споживачами, презентування, брендінгу, бізнес-планування, роботи у команді, та PR-діяльності щодо просування на ринок своєї розробки. Такий розподіл підвищує конкурентоздатність студентів на ринку праці. У контексті зазначеного, з'явилася потреба в інтеграції основ ведення бізнесу у фахову дизайнерську підготовку, оскільки навіть отримавши грунтовну професійну підготовку 3 дизайну, в умовах ринку праці молоді фахівці не можуть уникнути бізнес-законів цього середовища, для якого характерними є спільне вирішення проектних завдань, ведення комунікації у рамках проекту, спільна оцінка успішності проекту, створення бренду на продаж, робота 3 цільовою аудиторією свого продукту, робота 3 запереченнями замовника тощо. Принагідно, майбутні фахівці вважають комунікативні вміння головними для ефективної професійної соціалізації поза рамками академічного середовища (як підтверджує наше опитування молодих працівників-дизайнерів, вони витрачають від 50 до $80 \%$ робочого часу на той чи інший вид спілкування: усний чи письмовий), що дозволить молодим фахівцям просувати себе на ринку послуг, а також навчання через практику (“learning by doing”), що дозволить отримати актуальні професійні навички, які відповідають конкретному попиту й конкретним умовам.

Висновки. Здійснене дослідження дозволило нам виокремити актуальні теоретичні та прикладні проблеми фахової підготовки майбутніх дизайнерів у закладах вищої освіти України, які стосуються розуміння суті термінів "професійне мислення (майбутнього) дизайнера" та “структура професійного мислення майбутнього дизайнера", типології дизайну та сутнісного змісту дизайнерської професійної підготовки. Аналіз наукових джерел дозволив нам сформулювати власне визначення терміну “nрофесійне мислення (майбутнього) дизайнера", яке нами розуміється як клієнт-орієнтована проектна діяльність, яка поєднує логіку, інтуїиію, мистецтво, комерцію $і$ науку. А структура професійного мислення (майбутнього) дизайнера нами розглядається як динамічна спіраль циклів, які є послідовністю самодостатніх, самокомпенсаційних $i$ самовдоскональних мікропроцесів спрямованих на інтуїтивнохудожне $i$ критично-логічне осмислення $i$ реалізацію дизайнерського завдання.

Нами також з'ясовано, що проблема типології дизайну залишається дискусійною серед практикуючих теоретиків й на сьогодні, оскільки 


\section{АКТУАЛЬНІПРОБЛЕМИ ФАХОВОЇ ПІДГОТОВКИ МАЙБУТНІХ ДИЗАЙНЕРІВ У ЗАКЛАДАХ ВИЩОЇ ОСВІТИ УКРАЇНИ: ТЕОРЕТИЧНІ ТА ПРИКЛАДНІ АСПЕКТИ}

застосування ієрархічнӧ̈ (встановлення підпорядкованості) чи фасетної (вибір ознак класифікації незалежно як одна від одної, так і від семантичного змісту об'єкта, що класифікується) систем класифікації не забезпечують вирішення завдання. Перелік дизайн-дисциплін базується на головних ознаках способу мислення дизайнера.

Щодо фахової підготовки майбутніх дизайнерів у закладах вищої освіти, спостерігається поглиблення міждисциплінарності, а саме у напрямі крос-галузевої конвергенції та посилення уваги проблемі формування у студентів компетенцій самоосвіти. Подальший науковий пошук спрямуємо на вивчення можливостей поєднання обох трендів у модель формування готовності майбутніх дизайнерів одягу до самоосвіти на засадах міждисциплінарного підходу в мистецьких закладах вищої освіти.

\section{ЛІТЕРАТУРА}

1. Брюханова Г. В. Професійна підготовка майбутніх фахівців з дизайну друкованої продукції в Україні: історичний аспект. Неперервна професійна освіта: теорія і практика. 2014. Вип. 3 4. С. 113-117.

2. Габрель Т. М. Моделі типологічного різноманіття дизайн-дисциплін. Архітектурна освіта: проблеми та перспективи розвитку : Архітектурна освіта: проблеми та перспективи розвитку : матеріали науково-практичного семінару (м. Івано-Франківськ, Україна, 19 листопад 2015 р). Івано-Франківськ, 2015. С. 48-52.

3. Габрель Т. М. Культурна таксономія дизайндисциплін. Сучасне мистецтво. Київ, 2015. Вип. XI. C. $92-99$.

4. Габрель Т. М. Матеріалізація піраміди Маслоу в архітектурі багатофункціонального комплексу в м. Львові. Традиції та новації у вищій архітектурно-художній освіті. Харків, 2015. Вип. 1. С. 88-95.

5. Даниленко В. Я. Дизайн України у світовому контексті художньо-проектної культури: монографія. Харків, Колорит. 2005. 244 с.

6. Енгельмейєр П. К. Теорія творчості. Москва, 2010. 208 c. URL : https://platona.net/load/ knigi_po filosofii/filosofija nauki tekhniki/ ehngelmejer_teorija_tvorchestva_2010/30-1-0-4547 (дата звернення: 15.01.2020)

7. Освіта.UA: Курс “Дизайн-мислення для інновацій”, 2017. URL : http://osvita.ua/vnz/57406/ (дата звернення: 15.01.2020)

8. Прусак В. Ф. Становлення та розвиток дизайн-освіти в Україні (кінець XX - початок XXI ст.). Вісник Львівської національної академії мистецтв. 2016. Вип. 31. С. 71-82.
9. Саприкіна Л. В. Актуальні проблеми професійної підготовки майбутніх дизайнерів у вищих навчальних закладах. Вісник КрНУ імені Михайла Остроградського. 2018. Вип. 2 (109). Ч. 2. С. 108-113.

10. Турчин В. В., Луговський О. Ф. Навчальне макетування у сучасній проектній практиці. Промисловий дизайн. Мистецтвознавчі записки. 2019. Вип. 22. С. 183-191.

11. Фурса О. О. Тенденції розвитку дизайносвіти в Україні (друга половина XX початок XXI століття) : монографія; Ін-т пед. освіти і освіти дорослих НАПН України. Луганськ, 2012. $447 \mathrm{c.}$

12. Parsons G. The Philosophy of Design. Polity Press, 2016. 192 p.

\section{REFERENCES}

1. Bryukhanova, G. V. (2014). Profesiina pidgotovka maibutnikh fakhivtsiv $\mathrm{z}$ drukovanoho dysainu: Istorychii aspect [Professional training of future specialists in print production design in Ukraine: historical aspect]. Continuing professional education: theory and practice, Vol.3 4, pp. 113 117. [in Ukrainian].

2. Gabrel, T. M. (2015). Kulturna Taksomia dysain distsyplin [The cultural taxonomy of design disciplines]. Modern Art. Kyiv, pp.92-99. [in Ukraininan].

3. Gabrel, T. M. (2015). Modeli typologichnoi riznomznitnosti dysain dystsyplin [Models of typological diversity in design disciplines]. Architectural Education: Challenges and Prospects for Development: Scientific and Practical Seminar, Ivano-Frankivsk, Ukraine, November 19, Iv.-Frankivsk. pp. 48-52. [in Ukrainian].

4. Gabrel, T. M. (2015). Materializatsia piramidy Maslou v arkhitekturi bagatofunktsionalnoho kompleksu v m. Lvovi [Materialization of the Maslow Pyramid in the Architecture of the Multifunctional Complex in Lviv]. Traditions and Innovations in Higher Architectural and Art Education. Kharkiv, Vol. 1, pp. 88-95. [in Ukrainian].

5. Danilenko, V. Ya. (2005). Dysain Ukrainy u svitovomu kontexti khudognio-proektnoi kultury: Monograpia [Design of Ukraine in the world context of art and design culture: Monograph]. Kharkiv, Koloryt, 244 p. [in Ukrainian].

6. Engelmeyer, P. K. (2010). Teoria Tvorchosti [Theory of Creativity]. Moscov. Available at: https:// platona.net/load/knigi_po filosofii/ filos ofi ja na u k t e k h n k i/ ehngelmejer teorija tvorchestva 2010/30-1-0-4547 (accessed 15 Feb.2020). [in Ukrainian].

7. Osvita.UA (2017). Kurs "Dysiin-Myslennia dlia 
innovatsii" ["Design-Thinking for Innovation" course]. Available at: http://osvita.ua/vnz/57406/ (accessed 15 Jan.2020). [in Ukrainian].

8. Prusak, V. F. (2016). Stanovlennia ta rozvytok dyzain-osvity v Ukraini (kinets XX - pochatok XXI st.). [Formation and development of design education in Ukraine (end of XX - beginning of XXI century]. Bulletin of the Lviv National Academy of Arts. No. 31. pp. 71-82. [in Ukrainian].

9. Saprykina, L. V. (2018). Aktualni problem profesiinoi pidgotovky maibutnikh dysianeriv u vyshcykh navchalnikh zakladkh [Current issues in training of the future designers in higher educational]. Bulletin for the Kryvyu Rih National University named after Mikhail Ostrogradsky, Vol. 2(109), pp.108-113. [in Ukrainian].
10. Turchyn, V. V. \& Lugovsky, A. F. (2017). Navchalne Maketuvannia u suchasni proektni praktitsi. Promyslovi Dysiin. [Training layout in modern design practice. Industrial design]. Artistic notes, Vol. 22., pp.183-191. [in Ukrainian].

11. Fursa, O. O. (2012). Tendetsii rozvytku dysain osvity v Ukraiini (druha polovyna XX st. - pochatok XXI st) [Trends in development of design education in Ukraine (second half of XX - beginning of XXI century]. Inst. Ped. education and adult education of the National Academy of Pedagogical Sciences of Ukraine. Lugansk, 447 p. [in Ukrainian].

12. Parsons, G. (2016). The Philosophy of Design. Polity Press. 192 p. [in English]. (accessed 10 March 2013)

Стаття надійшла до редакції 10.01.2020

\section{УДК $793.31(477.84)$}

DOI:

Людмила Щур, асистент кафедри музикознавства та методики музичного мистецтвва Тернопільського національного педагогічного університету імені Володимира Гнатюка

\section{СТРУКТУРНО-ФУНКЦІОНАЛЬНІ АСПЕКТИ ХОРЕОГРАФІЧНОЇ КУЛЬТУРИ ЗАХІДНОГО ПОДІЛЛЯ}

У статті висвітлено питання функціонування хореографічної культури у діяльності як дитячих аматорських танияювальних колективів, так $і$ студентських аматорських танцювальних ансамблів закладів вищої освіти, які працюють на теренах Західного Поділля. Зроблено коротку характеристику діяльності єдиного професійного академічного ансамблю танцью “Надзбручанка” у Західному Поділлі. Розглянуто основні аспекти створення таниювальних ансамблів, а також роль їх керівників. Виявлено стан збереження західноподільських танцювальних традицій та їх місие у репертуарі діючих хореографічних колективів.

Ключові слова: хореографічна культура; таниюювальні колективи; Західне Поділля.

Jim. 19.

Lyudmyla Shchur, Assistant of the Musicology and Methods of Music Department Ternopil Volodymyr Hnatyuk National Pedagogical University

\section{STRUCTURALAND FUNCTIONALASPECTS OF CHOREOGRAPHIC CULTURE OF WESTERN PODILLYA}

The folk choreographic culture of Western Podillya is a kind of chronicle of traditions, rituals and customs of the regional dance heritage, which is an integral part of the choreographic culture of Ukraine as a whole.

Given the processes of globalization in the modern world, the regional perspective of scientific research becomes especially relevant. However, despite numerous scientific works that cover the development and functioning of amateur dance groups, Western Podillya wasn't mentioned.

According to the Ternopil Regional Methodical Center of Folk Art (TRMCFA), as of 2018, there were 200 choreographic groups (about four thousand participants) in the cultural institutions in Ternopil region, including 12 folk and 23 exemplary ensembles.

Amateur choreographic art was also popularized among students in higher educational institutions of Western Podillya.

The Promin folk dance ensemble of Ternopil State Pedagogical Institute (now Ternopil Volodymyr Hnatyuk National Pedagigical University) dates back to 1969, the title was conferred in 1977 (leader - Honored Culture Worker of Ukraine Vasyl Pochynok).

Terebovlya Higher School of Culture (now Terebovlya College of Culture and Arts) is the only educational institution in Ternopil region for training specialists in the sphere of professional choreographic art development. 